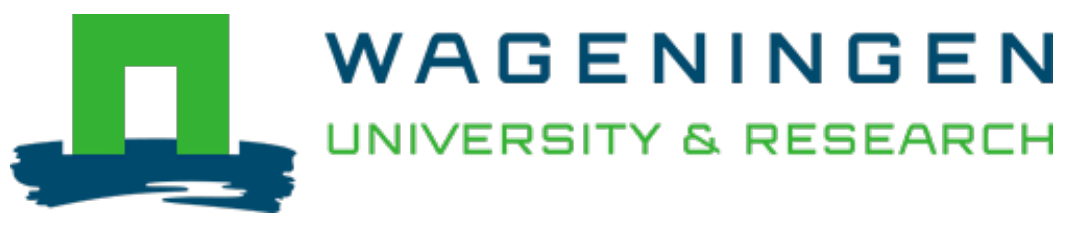

\author{
Changes in the physico-chemical properties of maize during natural fermentation \\ of mawè. \\ Journal of Cereal Science \\ Hounhouigan, D.J.; Nout, M.J.R.; Nago, C.M.; Houben, J.H.; Rombouts, F.M. \\ https://doi.org/10.1006/jers.1993.1027
}

This publication is made publicly available in the institutional repository of Wageningen University and Research, under the terms of article $25 \mathrm{fa}$ of the Dutch Copyright Act, also known as the Amendment Taverne. This has been done with explicit consent by the author.

Article 25 fa states that the author of a short scientific work funded either wholly or partially by Dutch public funds is entitled to make that work publicly available for no consideration following a reasonable period of time after the work was first published, provided that clear reference is made to the source of the first publication of the work.

This publication is distributed under The Association of Universities in the Netherlands (VSNU) 'Article $25 \mathrm{fa}$ implementation' project. In this project research outputs of researchers employed by Dutch Universities that comply with the legal requirements of Article $25 \mathrm{fa}$ of the Dutch Copyright Act are distributed online and free of cost or other barriers in institutional repositories. Research outputs are distributed six months after their first online publication in the original published version and with proper attribution to the source of the original publication.

You are permitted to download and use the publication for personal purposes. All rights remain with the author(s) and / or copyright owner(s) of this work. Any use of the publication or parts of it other than authorised under article $25 \mathrm{fa}$ of the Dutch Copyright act is prohibited. Wageningen University \& Research and the author(s) of this publication shall not be held responsible or liable for any damages resulting from your (re)use of this publication.

For questions regarding the public availability of this publication please contact openscience.library@wur.nl 


\title{
Changes in the Physico-Chemical Properties of Maize During Natural Fermentation of Mawè
}

\author{
D. J. HOUNHOUIGAN*§, M. J. R. NOUT $\dagger$, C. M. NAGO*, J. H. HOUBEN + \\ and F. M. ROMBOUTS $\dagger$ \\ * Université Nationale du Bénin, Faculté des Sciences Agronomiques, Abomey-Calavi, \\ Bénin, $\uparrow$ Agricultural University, Department of Food Science, Bomenweg 2, 6703 HD \\ Wageningen, The Netherlands and $\ddagger$ Utrecht University, Department of the Science of \\ Foods of Animal Origin, Yalelaan 2, Utrecht, The Netherlands
}

Received 13 July 1992; Accepted 18 November 1992

\begin{abstract}
The physical and chemical changes that occurred during a 72-h fermentation period were studied in two differently processed maize doughs from Bénin, referred to as home-produced and commercial mawè. The $\mathrm{pH}$ decreased from 6.1 to 3.5 in the commercial process and from 6.2 to 3.6 in the home-style process, whereas the titratable acidity increased from 0.2 to $1.7 \%$ (w/w, lactic acid) and from 0.3 to $2.3 \%$, respectively. Home-produced mawè had significantly higher levels of crude fat, crude fibre and ash compared with the commercial mawè, as a consequence of the difference in the processing methods. No marked changes in proximate composition occurred during subsequent fermentation. Commercial mawè was whiter than homeproduced mawè, and this whiteness increased with increasing fermentation time. Fermentation significantly increased the swelling and thickening capabilities of mawè, which were more pronounced in the commercial than in home-produced samples. Overall, the commercial mawè process appeared to be a technologically more advanced and effective method of mawè manufacture than the home process.
\end{abstract}

\section{Introduction}

Mawè is a sour dough, which has undergone natural fermentation for 1 to 3 days. It is made from dehulled maize, and, on this basis, is different from the whole maize dough used to prepare Ghanaian kenkey'. Mawe is used for the preparation of a variety of dishes in its area of origin, Bénin and Togo. Depending on its intended use and on individual taste preferences, consumers choose mawè on the basis of its sourness, whiteness and fineness.

An investigation carried out in the Bénin urban area showed that ready-to-use mawè had a titratable acidity of $1 \cdot 2-1 \cdot 4 \%(\mathrm{w} / \mathrm{w}$, as lactic acid), with $\mathrm{pH}$ values of approximately 4.2 in home-produced mawè and 3.8 in commercial mawè ${ }^{2}$. These degrees of sourness are generally accepted for the preparation of stiff gels (akassa, agidi, eko)

$\S$ Address for correspondence: Université Nationale du Bénin, Faculté des Sciences Agronomiques, Section de Nutrition et de Sciences Agro-Alimentaires, BP 526, Cotonou, République du Bénin. 
and porridge (koko). On the other hand, less sour mawè is preferred for steamed cooked bread (ablo), and more acid mawè is used for the preparation of porridge for sick people. In Bénin, mawè is a substitute for ogi (a fermented maize gruel fermented as a suspension) for akassa and porridge preparation.

The physical and chemical changes during the processing of cereal grains into ogi have been investigated ${ }^{3-5}$. As information on the physical and chemical changes during the processing of maize to mawè is lacking, this study was carried out to evaluate these changes.

\section{Mawè production}

\section{Experimental}

Home-produced mawè and commercial mawè were produced as illustrated in Figs 1 and 2, respectively. The processing was carried out by a local mawè producer, using the maize cultivar Sékou 85 provided by the International Institute of Tropical Agriculture, Bénin. The dough resulting from each process was divided between six plastic buckets with lids. Fermentation was at room temperature $\left(28-32{ }^{\circ} \mathrm{C}\right)$ and was carried out for $72 \mathrm{~h}$. Each process was carried out in duplicate.

\section{Sample treatment, packaging and preservation}

After $0,6,12,24,48$ and $72 \mathrm{~h}$ fermentation, one bucket of mawè from each process was taken for analysis. Sub-samples $(5 \mathrm{~g})$ were used for moisture determination. Portions $(100$ and $20 \mathrm{~g})$ were used for measurement of colour and determination of $\mathrm{pH}$ and titratable acidity, respectively. The remainder of the sample was packed in polyethylene bags, and held at $-50^{\circ} \mathrm{C}$ for later analysis: frozen samples of mawè were thawed overnight at $5{ }^{\circ} \mathrm{C}$ for viscosity measurement or dried in an air-oven at $60^{\circ} \mathrm{C}$ for $48 \mathrm{~h}$, ground in a Retsch ZM1 mill and dried further to constant weight at $103^{\circ} \mathrm{C}$. The dried sample was vacuum-sealed in laminated aluminium foil bags until determination of proximate composition.

\section{Chemical analysis}

$\mathrm{pH}$ and titratable acidity were measured by the method of Nout $e t$ al. ${ }^{6}$, modified as follows: the sample $(10 \mathrm{~g})$ was mixed with distilled water $(20 \mathrm{ml})$ and the $\mathrm{pH}$ measured using a Hanna $8417 \mathrm{pH}$ meter (Hanna Instruments, Limena, Italy). Subsequently, this suspension was mixed with distilled water $(70 \mathrm{ml})$ for determination of the titratable acidity. Moisture, crude protein, crude fat and ash contents were determined using $\mathrm{AACC}^{7}$ methods 44-15 A, 46-11 A, 30-25 and 08-01, respectively. Crude fibre content was determined as described by Osborne and Voogt ${ }^{8}$. Carbohydrate content was calculated by difference.

\section{Physical analysis}

The colour of mawè samples was measured with a Minolta CR-210 portable chromameter, using chromaticity co-ordinates $L^{*}, a^{*}, b^{*}$ and $\Delta E$ (illuminant $\mathrm{D} 65$, CIE 1976). The instrument was standardized with a standard white tile $(Y=94.8, x=0.3150$ and $y=0.3324)$. The pasting characteristics were measured using a Brabender Pt 100 Viscograph (Brabender OHG Duisburg, Germany). A $700 \mathrm{cmg}$ sensitivity cartridge was used. Slurries containing $10.0 \%(\mathrm{w} / \mathrm{v})$ dry matter were analysed. The total weight of slurry in the Viscograph bowl was $450 \mathrm{~g}$. The mixture was heated at $1.5^{\circ} \mathrm{C} / \mathrm{min}$ from $30^{\circ} \mathrm{C}$ up to $92^{\circ} \mathrm{C}$, held at $92^{\circ} \mathrm{C}$ for $15 \mathrm{~min}$ and then cooled to $50^{\circ} \mathrm{C}$. The Viscograms were interpreted as described by Banigo et al. ${ }^{9}$. 


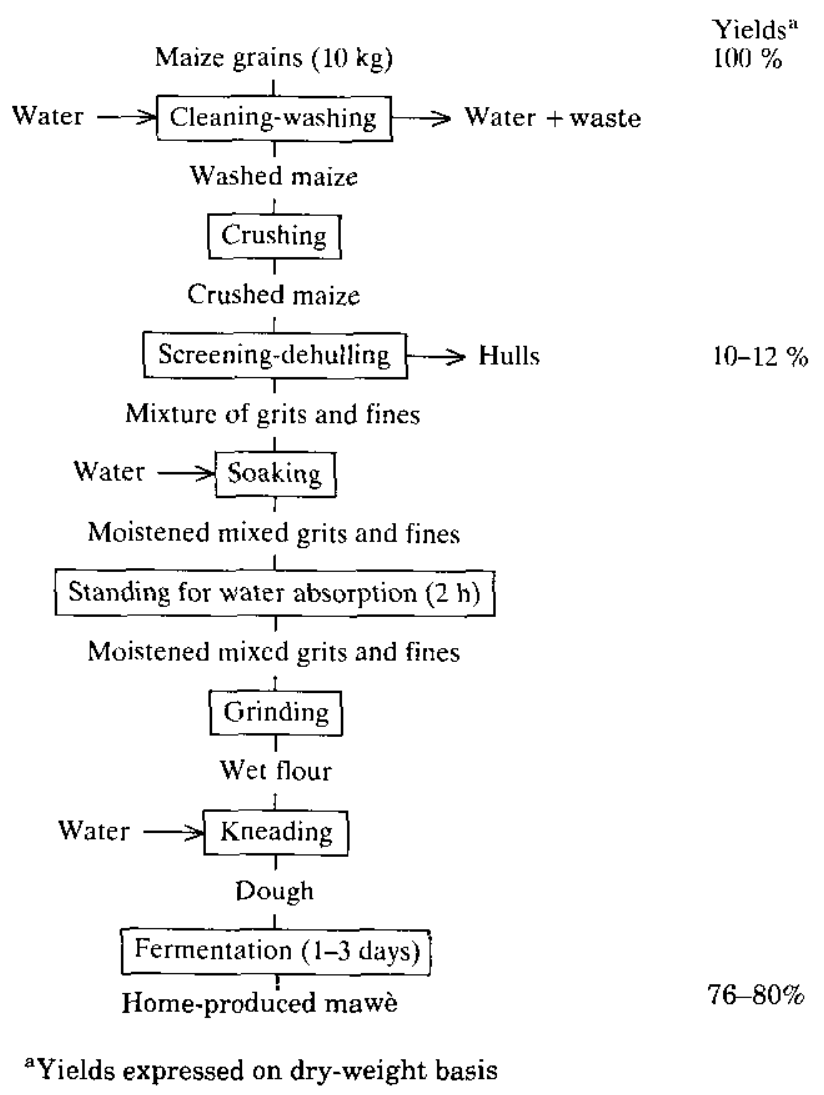

FIGURE 1. Flow diagram for mawè production: home-style process.

\section{Statistical analysis}

Samples from different processes and fermentation periods were statistically compared using analysis of variance ${ }^{10}$ and Duncan's multiple-range test ${ }^{11}$.

\section{Yield of mawè}

\section{Results and Discussion}

The yield of mawè from three replications of each process ranged between 76 and $80 \%$ for the home-style process and between 65 and $71 \%$ for the commercial process (dryweight basis). The lower yield in the commercial process was caused mainly by the thorough washing of grits in water to remove hulls and germs, and to the concomitant loss of extractable dry matter in the washing water. In the home-style process, this operation was not applied: the mixture of grits and fines obtained after screeningdehulling was soaked in water without washing (Figs 1 and 2).

A significant $(P<0.05)$ increase in the moisture content of mawè was observed during the fermentation period (Table I). This is caused by the combined effects of dry matter consumption and production of water during aerobic and anaerobic catabolism by yeasts and heterofermentative lactic acid bacteria ${ }^{2,12}$. 


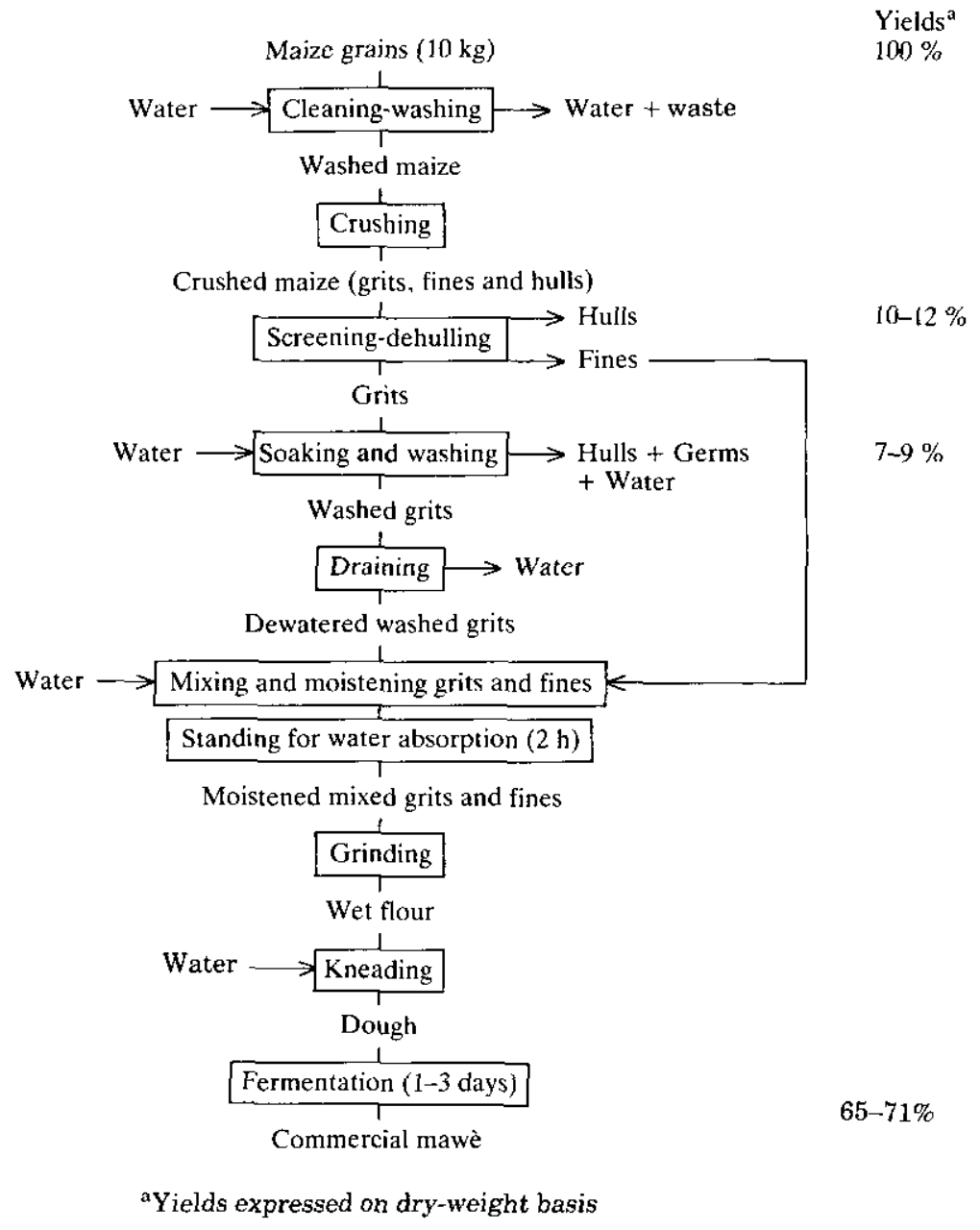

FIGURE 2. Flow diagram for mawè production: commercial process.

TABLE I. The influence of fermentation time on the moisture content of mawè

\begin{tabular}{|c|c|c|}
\hline \multirow[b]{2}{*}{$\begin{array}{l}\text { Fermentation } \\
\text { time }(\mathrm{h})\end{array}$} & \multicolumn{2}{|c|}{$\begin{array}{c}\text { Moisture content } \\
(\%, w / w, \text { fresh weight })\end{array}$} \\
\hline & $\begin{array}{l}\text { Home-produced } \\
\text { mawè }\end{array}$ & $\begin{array}{c}\text { Commercial } \\
\text { mawè }\end{array}$ \\
\hline 0 & $45 \cdot 5$ & 460 \\
\hline 6 & $45 \cdot 4$ & 46.0 \\
\hline 12 & $46 \cdot 1$ & $46 \cdot 2$ \\
\hline 24 & $46 \cdot 3$ & $46 \cdot 8$ \\
\hline 48 & $47 \cdot 2$ & $48 \cdot 4$ \\
\hline 72 & $48 \cdot 3$ & $48 \cdot 2$ \\
\hline
\end{tabular}

a Mean of two independent determinations. Replicates were within $3 \%$ of the mean. 


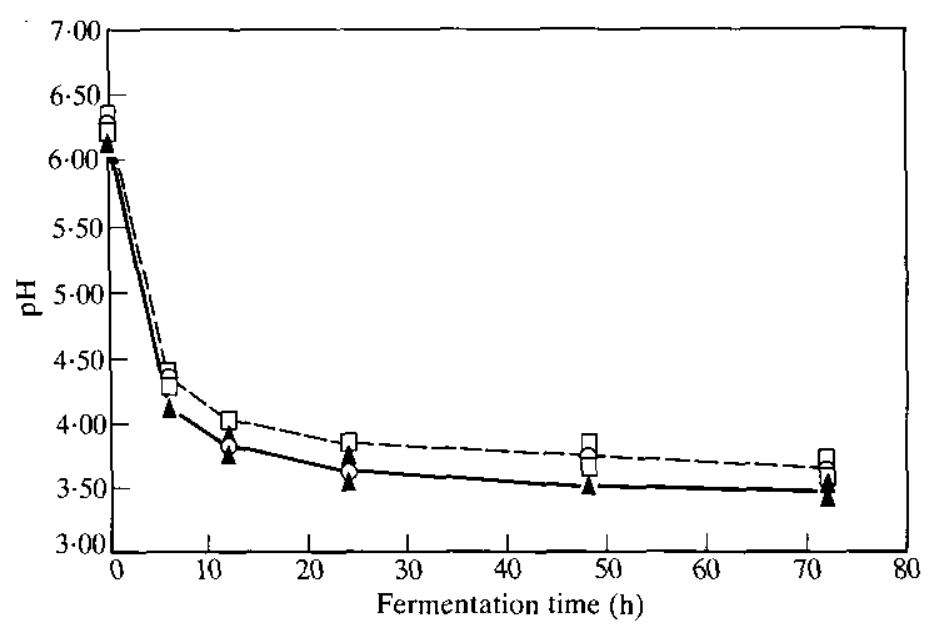

FIGURE 3. The influence of fermentation time on the pH of mawè. Home-produced mawè $(\square)$, commercial mawè $(\boldsymbol{A})$.

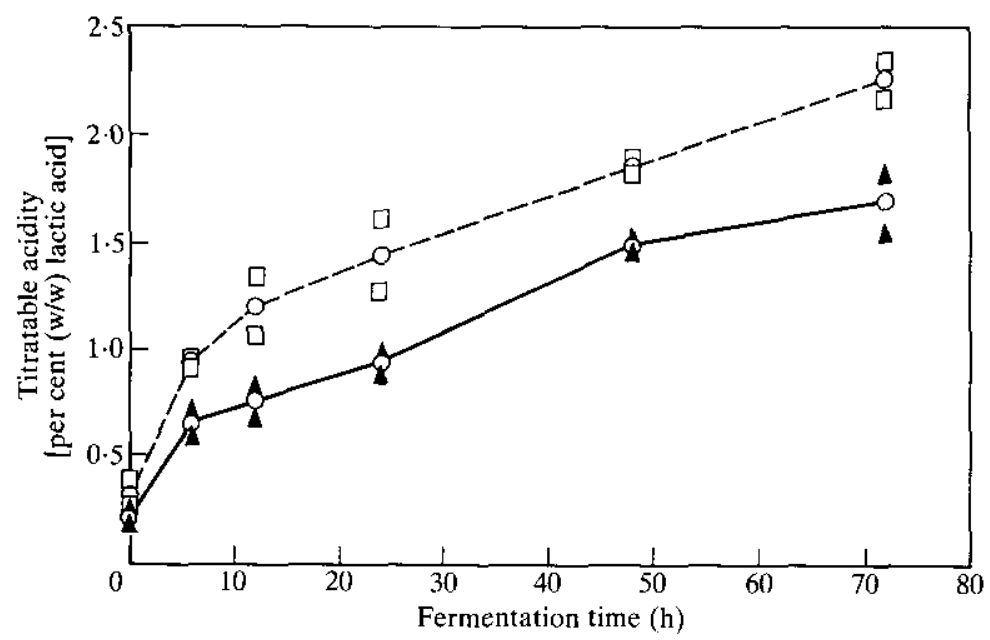

FIGURE 4. The influence of fermentation time on the titratable acidity of mawè. Home-produced mawè $(\square)$, commercial mawè $(\boldsymbol{A})$.

\section{$p H$ and titratable acidity}

The changes in $\mathrm{pH}$ and titratable acidity in both types of mawè are shown in Figs 3 and 4 , respectively. The titratable acidity of home-produced and commercial mawè increased from $0.3 \%$ and $0.2 \%(\mathrm{w} / \mathrm{w}$, calculated as lactic acid), at the start of the fermentation $\left(t_{0}\right)$, to $2.3 \%$ and $1.7 \%$, respectively, after $72 \mathrm{~h}$ fermentation $\left(t_{72}\right)$. The $\mathrm{pH}$ of homeproduced mawè still remained the highest.

In the commercial process, water-extractable sugars and proteins are partly lost during the washing of the grits. In the home-style process, the greater availability of fermentable sugars led to enhanced production of organic acids (Fig. 4). But the home- 
TABLE II. The proximate compositions of maize raw material, and of mawè at the start $\left(t_{0}\right)$ and after $24 \mathrm{~h}\left(t_{24}\right)$ and $72 \mathrm{~h}\left(t_{72}\right)$ of fermentation ${ }^{\mathrm{a}}$

\begin{tabular}{|c|c|c|c|c|c|c|c|}
\hline & \multirow{2}{*}{$\begin{array}{c}\text { Maize } \\
\text { (raw } \\
\text { material) }\end{array}$} & \multicolumn{3}{|c|}{ Home-produced mawè } & \multicolumn{3}{|c|}{ Commercial mawè } \\
\hline & & $t_{0}$ & $t_{\mathbf{2 4}}$ & $t_{72}$ & $t_{0}$ & $t_{24}$ & $t_{72}$ \\
\hline \multicolumn{8}{|l|}{$(\%, d w b)^{b}$} \\
\hline Crude protein ${ }^{\mathrm{c}}$ & $11 \cdot 2$ & $11 \cdot 3 a^{\mathrm{d}}$ & $11 \cdot 2 a$ & $11 \cdot 3 a$ & $10 \cdot 3 a$ & $10 \cdot 5 a$ & $10 \cdot 7 a$ \\
\hline Crude fat & $4 \cdot 9$ & $3 \cdot 8 a$ & $3 \cdot 8 a$ & $3 \cdot 9 a$ & $1 \cdot 0 b$ & $1 \cdot 1 b$ & $1 \cdot 2 b$ \\
\hline Crude fibre & 1.8 & $0.9 a$ & $0 \cdot 9 a$ & $1 \cdot 0 a$ & $0 \cdot 5 b$ & $0.5 b$ & $0 \cdot 6 b$ \\
\hline Ash & $1 \cdot 5$ & $1 \cdot 3 a$ & $1 \cdot 3 a$ & $1 \cdot 3 a$ & $0 \cdot 5 b$ & $0.5 b$ & $0.5 b$ \\
\hline Carbohydrate & $80 \cdot 6$ & $82 \cdot 7 a$ & $82 \cdot 8 a$ & $82 \cdot 5 a$ & $87.6 b$ & $87 \cdot 4 b$ & $87.0 b$ \\
\hline $\begin{array}{l}\text { a Mean of two ind } \\
\text { b } \mathrm{dwb}=\mathrm{dry} \text {-weigl } \\
\mathrm{N} \times 6 \cdot 25 \text {. } \\
\mathrm{d} \text { a, }, \text { Means with } \\
\text { e Calculated by di }\end{array}$ & $\begin{array}{l}\text { ndent dete } \\
\text { sis. } \\
\text { same lett } \\
\text { nce. }\end{array}$ & ions. & at & & & & \\
\hline
\end{tabular}

produced mawè also had a higher protein content and consequently a higher buffering capacity ${ }^{13}$. The latter was responsible for the higher $\mathrm{pH}$ compared with the commercial product.

In the commercial product, the lower titratable acidity was, nevertheless, sufficient to create an extracellular $\mathrm{pH}^{14}$ that limited further growth. The buffering effect of the higher protein content in the home-produced mawè necessitated larger amounts of titratable acidity to reach an inhibitory extracellular $\mathrm{pH}$. In fact, after $72 \mathrm{~h}$ fermentation, the home-produced mawè had not yet stabilized. A buffering action by proteins was observed also in $\mathrm{ogi}^{3}$ and Ghanaian maize dough ${ }^{15}$.

Our findings confirm that the extent of fermentation of cereal products cannot be evaluated merely on the basis of their $\mathrm{pH}$. Consequently, evaluation of fermentation rates requires monitoring of both $\mathrm{pH}$ and titratable acidity. Earlier experiments ${ }^{2}$ showed that at the moment of use, market samples of commercial mawè had a titratable acidity of $1.4 \pm 0.5 \%(\mathrm{w} / \mathrm{w}$, as lactic acid) and home-produced mawè contained $1.2 \pm 0.2 \%$ titratable acidity. These levels of acidity were achieved within $24 \mathrm{~h}$ of fermentation in commercial mawè or within $12 \mathrm{~h}$ of fermentation in home-produced mawe under the conditions of the present study.

\section{Proximate composition}

From Table II, it can be seen that the processing method had only a slight effect on the crude protein content but the crude fat, ash, crude fibre and carbohydrate contents of mawè were influenced significantly $(P<0 \cdot 01)$. The maize cultivar Sékou 85 sample used contained about $11.2 \%$ crude protein, which was reduced to about $10.3 \%$ on conversion to unfermented commercial mawè (about $8 \%$ loss in $t_{0}$ sample) and remained constant on conversion to unfermented home-produced mawè.

A substantial loss of protein (40-50\%) was reported during the processing of maize to $\mathrm{ogi}^{3,16}$. Compared with unprocessed maize, the crude fat content was reduced by 
TABLE III. The influence of fermentation time on the colour parameters of mawè

\begin{tabular}{|c|c|c|c|c|c|c|c|c|}
\hline & \multicolumn{4}{|c|}{ Home-produced mawè } & \multicolumn{4}{|c|}{ Commercial mawè } \\
\hline & $L^{*}$ & $a^{*}$ & $b^{*}$ & $\Delta E$ & $L^{*}$ & $a^{*}$ & $b^{*}$ & $\Delta E$ \\
\hline $0 \mathrm{~h}$ & $78 \cdot 0$ & -1.8 & $11 \cdot 8$ & $22 \cdot 6$ & $81 \cdot 0$ & $-2 \cdot 2$ & $9 \cdot 2$ & $18 \cdot 7$ \\
\hline $6 \mathrm{~h}$ & $78 \cdot 4$ & $-2 \cdot 0$ & $11 \cdot 5$ & $22 \cdot 1$ & $81 \cdot 1$ & $-2 \cdot 4$ & $8 \cdot 8$ & $18 \cdot 5$ \\
\hline $12 \mathrm{~h}$ & $78 \cdot 9$ & $-2 \cdot 1$ & $11 \cdot 4$ & $21 \cdot 6$ & $81 \cdot 8$ & $-2 \cdot 3$ & $8 \cdot 7$ & $17 \cdot 9$ \\
\hline $24 \mathrm{~h}$ & $79 \cdot 2$ & $-2 \cdot 2$ & $11 \cdot 3$ & $20 \cdot 9$ & $82 \cdot 5$ & $-2 \cdot 4$ & $8 \cdot 4$ & $16 \cdot 8$ \\
\hline $48 \mathrm{~h}$ & $79 \cdot 9$ & $-2 \cdot 3$ & $11 \cdot 4$ & $20 \cdot 4$ & 83.4 & $-2 \cdot 6$ & $8 \cdot 1$ & $15 \cdot 9$ \\
\hline $72 \mathrm{~h}$ & $80 \cdot 8$ & $-2 \cdot 3$ & $11 \cdot 3$ & $19 \cdot 6$ & $83 \cdot 7$ & $-2 \cdot 6$ & $8 \cdot 4$ & $15 \cdot 7$ \\
\hline
\end{tabular}

a Mean of two independent determinations.

$L^{*}$, luminosity parameter. Replicates were within $1.5 \%$ of the mean.

$a^{*}$, greenness-redness parameter. Replicates were within $9 \%$ of the mean.

$b^{*}$, blueness-yellowness parameter. Replicates were within $8 \%$ of the mean.

$\Delta E$, total colour difference with standard white tile. Replicates were within $5 \%$ of the mean.

about $80 \%$ in commercial mawè and by $22 \%$ in home-produced mawè; the ash content by about $67 \%$ in commercial mawè and $13 \%$ in home-produced mawè; and the crude fibre content by about $72 \%$ in commercial mawè and $50 \%$ in home-produced mawè. No marked changes in proximate composition occurred during subsequent fermentation. The only difference between the commercial process and the home process was the washing of the grits before milling, which may explain the difference in proximate composition between both types of mawè.

\section{Changes in colour}

Colour parameters recorded during mawè fermentation are given in Table III. The fermentation period and the processing method both affected the colour parameters $L^{*}$ (luminosity), $a^{*}$ (greenness-redness) and $\Delta E$ (total colour difference with standard white tile) significantly $(P<0 \cdot 01)$. Commercial mawè was brighter than home-produced mawè, and the $L^{*}$ values increased with increasing fermentation time, while $a^{*}$ and $\Delta E$ values decreased correspondingly.

The results suggest that the luminosity (whiteness) of the product became more intense during the course of the fermentation. On the other hand, a high correlation $(r \geqslant 0.96)$ was observed between $L^{*}$ value and the moisture content of the samples obtained at different fermentation times. Furthermore, unfermented samples at different levels of moisture content showed a similar correlation between their respective $L^{*}$ values and moisture contents (results not included). This would suggest that the increase in the $L^{*}$ values (or in the luminosity) of the product was due mainly to the increase of the moisture contents during the course of the fermentation.

\section{Viscograph characteristics}

The pasting characteristics, which developed during the fermentation of both types of mawè, are listed in Table IV. Fermentation time had no significant effect on the gelatinization temperature $\left(T_{\mathrm{g}}\right)$, nor on the time to reach $T_{\mathrm{g}}\left(M_{\mathrm{g}}\right)$. On the other hand, 
TABLE IV. The influence of fermentation time on the pasting behaviour of mawè

\begin{tabular}{|c|c|c|c|c|c|c|c|c|}
\hline & \multicolumn{4}{|c|}{ Home-produced mawè } & \multicolumn{4}{|c|}{ Commercial mawè } \\
\hline & $0 \mathrm{~h}$ & $24 \mathrm{~h}$ & $48 \mathrm{~h}$ & $72 \mathrm{~h}$ & $0 \mathrm{~h}$ & $24 \mathrm{~h}$ & $48 \mathrm{~h}$ & $72 \mathrm{~h}$ \\
\hline$T_{\mathrm{g}}\left({ }^{\circ} \mathrm{C}\right)$ & $72 \cdot 3$ & $73 \cdot 2$ & 72 & $72 \cdot 8$ & $69 \cdot 9$ & $70 \cdot 9$ & $71 \cdot 3$ & 71 \\
\hline$M_{\mathrm{g}}(\mathrm{min})$ & $28 \cdot 2$ & $28 \cdot 8$ & $28 \cdot 6$ & $28 \cdot 5$ & 26.7 & $27 \cdot 3$ & $27 \cdot 5$ & $27 \cdot 5$ \\
\hline$M_{\mathrm{n}}(\min )$ & $38 \cdot 7$ & $40 \cdot 2$ & $40 \cdot 1$ & $39 \cdot 8$ & 36.6 & $40 \cdot 5$ & $40 \cdot 3$ & $39 \cdot 8$ \\
\hline$M_{n}-M_{\mathrm{z}}(\min )$ & $10 \cdot 5$ & $11 \cdot 4$ & $11 \cdot 5$ & $11 \cdot 3$ & $9 \cdot 9$ & $13 \cdot 2$ & $12 \cdot 8$ & $12 \cdot 3$ \\
\hline$V_{\mathrm{m}}^{\mathrm{n}}(\mathrm{BU})^{\mathrm{b}}$ & 254 & 344 & 396 & 415 & 233 & 560 & 661 & 681 \\
\hline$V_{\mathrm{r}}^{\mathrm{m}}(\mathrm{BU})$ & 226 & 293 & 311 & 324 & 148 & 424 & 426 & 426 \\
\hline$V_{\mathrm{e}}^{r}(\mathrm{BU})$ & 493 & 630 & 686 & 708 & 392 & 898 & 918 & 983 \\
\hline$V_{m}-V_{\mathrm{r}}(\mathrm{BU})$ & 28 & 51 & 85 & 91 & 85 & 136 & 235 & 255 \\
\hline$V_{\mathrm{e}}-V_{\mathrm{m}}(\mathrm{BU})$ & 239 & 286 & 290 & 293 & 159 & 338 & 257 & 302 \\
\hline$V_{\mathrm{e}}-V_{\mathrm{r}}(\mathrm{BU})$ & 267 & 337 & 375 & 384 & 244 & 474 & 492 & 557 \\
\hline
\end{tabular}

${ }^{a}$ Mean of two independent determinations.

$T$, replicates were within $2 \%$ of the mean.

$M_{\mathrm{g}}, M_{\mathrm{n}}$, replicates were within $3 \%$ of the mean.

$V_{\mathrm{m}}, V_{\mathrm{r}}, V_{\mathrm{e}}$, replicates were within $10 \%$ of the mean.

$\checkmark \mathrm{BU}$, Brabender unit.

$T_{\mathrm{g}}$, gelatinization temperature; $M_{\mathrm{g}}$, time to reach $T_{\mathrm{g}} ; M_{\mathrm{n}}$, time to reach $V_{\mathrm{m}} ; M_{\mathrm{n}}-M_{\mathrm{g}}$, ease of cooking; $V_{\mathrm{m}}$, maximum viscosity during heating; $V_{r}$, viscosity after $15 \mathrm{~min}$ at $92^{\circ} \mathrm{C} ; V_{\mathrm{e}}$, viscosity after cooling to $50^{\circ} \mathrm{C}$; $V_{\mathrm{m}}-V_{\mathrm{r}}$, stability of the starch; $V_{\mathrm{e}}-V_{\mathrm{m}}$, setback value; $V_{\mathrm{e}}-V_{\mathrm{r}}$, index of gelatinization.

maximum viscosity $\left(V_{\mathrm{m}}\right)$, viscosity after $15 \mathrm{~min}$ at $92{ }^{\circ} \mathrm{C}\left(V_{\mathrm{r}}\right)$, viscosity after cooling to $50{ }^{\circ} \mathrm{C}\left(V_{\mathrm{e}}\right)$, time to reach $V_{\mathrm{m}}\left(M_{\mathrm{n}}\right)$, stability value of the starch $\left(V_{\mathrm{m}}-V_{\mathrm{r}}\right)$, setback value $\left(V_{\mathrm{e}}-V_{\mathrm{m}}\right)$ and index of gelatinization $\left(V_{\mathrm{e}}-V_{\mathrm{r}}\right)$, all increased with fermentation time. The biggest difference was observed between the unfermented sample and the fermented samples. This is in agreement with the report of Banigo et al. ${ }^{9}$ that fermentation markedly increased the swelling and thickening characteristics of ogi.

Adeyemi and Beckley ${ }^{4}$ also found that the peak viscosity of soured maize flour was much higher than that of the unsoured maize flour. In contrast, Sefa-Dedeh ${ }^{17}$ found that the fermentation of maize dough drastically decreased the viscosity characteristics of Ghanaian-type corn dough. Adeyemi ${ }^{18}$ also found that fermentation of sorghum flour samples reduced their peak viscosities. The composition of the fermented substrate, which will be affected by the nature of the raw material used and the processing method, probably affected the behaviour of the paste during the heating, holding and cooling cycles. Adeyemi and Beckley ${ }^{4}$ suggested that the content of damaged starch granules, the alpha-amylase activity and the $\mathrm{pH}$ of the product would be factors having a more important influence than the presence of acetate ions, as suggested by Banigo et al ${ }^{9}$.

There was a significant $(P<0.01)$ increase in the ease of cooking $\left(M_{\mathrm{n}}-M_{\mathrm{g}}\right)$ of the fermented product, concomitant with the increased time to reach maximum viscosity $\left(M_{n}\right)$. This finding contrasts with previous results on maize ogi ${ }^{4}$, and corroborates the need for more research in order to understand the pasting behaviour of fermented cereal products.

It can be seen also that the processing method affected the gelatinization temperature $\left(T_{\mathrm{g}}\right)$ significantly $(P<0.01)$, the time to reach $T_{\mathrm{g}}\left(M_{\mathrm{g}}\right)$, the ease of cooking $\left(M_{\mathrm{n}}-M_{\mathrm{g}}\right)$, 
the maximum viscosity $\left(V_{\mathrm{m}}\right)$, the viscosity after $15 \mathrm{~min}$ at $92^{\circ} \mathrm{C}\left(V_{\mathrm{r}}\right)$, the viscosity after cooling to $50^{\circ} \mathrm{C}\left(V_{\mathrm{e}}\right)$, the stability of the starch $\left(V_{\mathrm{m}}-V_{\mathrm{r}}\right)$ and the index of gelatinization $\left(V_{\mathrm{e}}-V_{\mathrm{r}}\right)$. The viscosity and the ease of cooking values were higher with mawè obtained by the commercial process, whereas $T_{\mathrm{g}}$ and $M_{\mathrm{g}}$ values were lower.

These results are in accordance with those obtained previously ${ }^{2}$. For Nigerian ogi and Ghanaian maize dough, high gelatinization temperatures have been attributed to greater particle size ${ }^{17,19,20}$, as well as to reduced starch content ${ }^{19,20}$ : this may explain the behaviour of home-made mawè during heating. The higher crude fibre and crude fat contents of home-made mawè may have reduced the viscosities observed in this product, as reported for ogi obtained from dry milled maize compared with the viscosities of ogi from steeped whole maize ${ }^{20}$.

\section{Conclusion}

The commercial process can be considered a technologically more advanced and more effective method of mawè production, compared with the home process. Its adoption was dictated by the market demand for a product as white and fine as possible, having maximum swelling and thickening characteristics. Considering that the loss of protein is low during commercial mawè processing, and in view of the superior pasting behaviour, commercial mawè may be considered to be of superior quality.

Facilities and technical assistance provided by the Dutch-Béninese university co-operation programme, by the European Community (through the 'Institut de Recherche Agronomique Tropicale', Montpellier), and by the International Foundation for Science to one of us (D. J.H.) are gratefully acknowledged. The authors thank Jurgen Jansen, Boniface Ayénan and Erix Schokker for their skilled assistance.

\section{References}

1. Steinkraus, K. H. (ed.) in 'Handbook of Indigenous Fermented Foods', Marcel Dekker, New York (1983) pp 220-226.

2. Hounhouigan, D. J., Nout, M. J. R., Nago, C. M., Houben, J. H. and Rombouts, F. M. Int. J. Food Sci. Technol. In press.

3. Banigo, E. O. I. and Muller, H. G. J. Sci. Food Agric. 23 (1972) 101-111.

4. Adeyemi, I. A. and Beckley, O. J. Cereal Sci. 4 (1986) 353-360.

5. Adeyemi, I. A., Osunsami, A. T. and Fakorede, M. A. B. J. Food Sci. 52 (1987) 322-324.

6. Nout, M. J. R., Rombouts, F. M. and Havelaar, A. Int. J. Food Microbiol. 8 (1989) 351-361.

7. American Association of Cereal Chemists, Approved Method of the AACC, St Paul, Minnesota (1984) 8 th edn.

8. Osborne, D. R, and Voogt, P. in 'The Analysis of Nutrients in Foods', Academic Press, London (1978) pp $151-153$.

9. Banigo, E. O. I., de Man, J. M. and Duitschaever, C. L. Cereal Chem. 51 (1974) 559-573.

10. Snedecor, W. G. and Cochran, W. G. in 'Statistical Methods', 8 th edn, Iowa State University Press, Ames (1989) pp 38-63.

11. Duncan, D. B. Biometrics 11 (1955) 1.

12. Hounhouigan, D. J., Nout, M. J. R., Nago, C. M., Houben, J. H. and Rombouts, F. M. Int. J. Food. Microbiol. In press.

13. Bender, A. E. in 'Dictionary of Nutrition and Food Technology', Butterworths, London (1965). 
14. McFall, S. M. and Montville, T. J. J. Ind. Microbiol. 8 (1989) 335-340.

15. Plahar, W. A. and Leung, H. K. J. Sci. Food Agric. 33 (1982) 555-558.

16. Oke, O. L. Food Technol. 21 (1967) 202-204.

17. Sefa-Dedeh, S. Trop. Sci. 29 (1989) 21-32.

18. Adeyemi, I. A. Cereal Sci. 1 (1983) 221-227.

19. Akingbala, J. O. and Rooney, L. W. J. Food Proc. Pres. 11 (1987) 13-24.

20. Akingbala, J. O., Onochie, E. U., Adeyemi, I. A. and Oguntimein, G. B. J. Food Proc. Pres. 11 (1987) 1-11. 